\title{
ENABLING POLICIES, DISABLING PRACTICES
}

\author{
Zubeida Desai \\ University of the Western Cape
}

We often receive positive comment from overseas on the new South African language policy which acknowledges eleven official national languages. This article critically explores the effect of this policy within the confines of education. Three areas are investigated: important shifts in language policy since 1994; language medium practice in a grade 4 class in a primary school in a predominantly black Western Cape urban area; the discrepancy between the intentions of the policy makers and (the negative effects on educational practice. The argument is presented that ultimately the issues surrounding implementation will determine whether or not language policy will be successful or not. The case study used shows that there is a need to make language practice such that it facilitates rather than frustrates the learning process.

Vanuit die buiteland word dikwels positiewe kommentaar gelewer oor die nuwe SuidAfrikaanse taalbeleid wat elf amptelike landstale erken. In hierdie artikel word ' $n$ kritiese ondersoek gedoen van die uitwerking van hierdie beleid binne die kader van die onderwys. Drie areas word ondersoek:

Belangrike skuiwe in taalbeleid sedert 1994.

Die praktyk van taalonderrigbeleid in ' $n$ Graad 4 klas in 'n laerskool in 'n oorwegend swart Wes-Kaapse stedelike woongebied.

Die diskrepansie tussen die beoogde bedoelings van die taalbeleidmakers en die neerslag in die onderrigpraktyk.

Dit word beweer dat dit op die ou end die kwessies rondom implimentering sal wees wat die sukses al dan nie van taalbeleid sal bepaal. Hierdie gevallestudie toon duidelik dat die behoefte bestaan om taalonderrigpraktyk so in te rig dat dit die leerproses eerder sal fasiliteer as frustreer.

\section{INTRODUCTION}

Since the first democratic elections in South Africa, the new government has been developing policies aimed at transforming practices in various domains to benefit as many of the population as possible. One such domain is language use, and, more specifically, language in education. In this paper I use a suggestive example to explore the extent to which the language policies of the new government have an effect on educational practice. I examine:

major developments in language policy since 1994

language in education policy in practice in a Grade 4 classroom in a primary school in the Western Cape

the disjuncture between the professed intentions of the policy makers and how the policies are realised in practice. 
Many people from outside South Africa have commented very favourably on our new language policy. Professor Adams, for example, used the term 'linguistic liberalism' when talking about the language provisions in The Constitution of the Republic of South Africa (1996) and the Language in Education Policy Document (July 1997). Such remarks prompted the title of this article. I would like to make a cautionary comment in this regard. Language policies in Africa are notorious for remaining mere statements of intent. An example is the OAU Language Plan of 1986. It represents an impressive plan to promote African languages in domains other than the ones in which they have conventionally been used. But thirteen years later, it remains largely a plan. It remains to be seen whether the Harare Conference Report and Recommendation of 1997 will be any different. Ultimately, however, it is issues of implementation that determine whether a policy is successful or not. And it is this aspect that I focus on in my article.

At the Tenth World Congress of Comparative Education Societies in Cape Town in (CCES), a persistent theme was the negative attitudes towards African languages by the speakers of these languages and how we can change these attitudes. On the face of it, it seems unlikely that these attitudes can be changed through direct means. If, however, we can change practices in South Africa, changes in attitude will follow suit - whether these be racist attitudes, sexist attitudes or attitudes towards particular languages.

At the same conference, people spoke about multilingualism in very many different contexts. I think we need to distinguish between some of these contexts, so that we do not think in terms of a single solution for very diverse contexts. There is a world of difference between those who learn an additional language to widen their repertoire and those who are forced to learn an additional language in order to gain access to education and to be able to participate satisfactorily in the wider society. One can further sub-divide the latter group into those who are learning that additional language, immersed in it (e.g. immigrant children in the USA or UK), and those who are having to learn that language in an environment where it is not often used (e.g. the children of Khayelitsha, Cape Town, who are the focus of the second section of this paper).

\section{MAJOR DEVELOPMENTS IN LANGUAGE POLICY SINCE 1994}

The key features of the current language policy of South Africa are outlined in The Constitution of the Republic of South Africa, Act 108 of 1996. They may be summarised as follows:

- The official languages are, in alphabetical order, Afrikaans, English, isiNdebele, isiXhosa, isiZulu, Sepedi, Sesotho, Setswana, siSwati, Tshivenda and Xitsonga.

- The onus is on the state to take practical and positive measures to elevate the status and advance the use of the indigenous languages ${ }^{1}$ of our people

- The national and provincial governments must use at least two of the official languages for the purposes of government.

- National and provincial governments must regulate and monitor the use of official languages. All official languages must enjoy parity of esteem and be treated equitably.

- A Pan South African Language Board established by national legislation must promote and create conditions for the development and use of all official languages; the Khoi, 
Nama and San languages; and sign language; and promote and ensure respect for all languages commonly used by communities in South Africa, including German, Greek, Gujarati, Hindi, Portuguese, Tamil, Telegu, and Urdu; Arabic, Hebrew, Sanskrit and other languages used for religious purposes in South Africa

(Act 108 of 1996:4-5).

Direct government responsibility applies to the eleven official languages only. It is the responsibility of the Pan South African Language Board to promote other languages mentioned in the Constitution, in addition to the eleven official languages. It is clear from the above that the Constitution does provide a framework to honour multilingualism. However, effecting a change on public consciousness and practice is not a simple matter.

In July 1997, the Department of Education formally announced its language in education policy. The two policy documents are: Language in Education Policy in terms of Section 3(4)(m) of the National Education Policy Act, 1996 (Act 27 of 1996), and the Norms and Standards regarding Language Policy published in terms of Section 6(1) of the South African Schools Act, 1996. According to the Department, the two documents are complementary and should at all times be read together. For the purposes of this article, I am going to focus on the Norms and Standards document as its main concern is with the practical implications of implementing the new policy. First, however, the key elements of the Language in Education Policy document must be understood.

\section{THE LANGUAGE IN EDUCATION POLICY DOCUMENT}

The Department of Education regards this document as the first contribution to a continuous process of developing an appropriate Language in Education Policy (LiEP). The new LiEP is 'meant to facilitate communication across the barriers of colour, language and region, while at the same time creating an environment in which respect for languages other than one's own would be encouraged' (Language in Education Policy Document, 1997: 2). The underlying principle of the new policy is to maintain the home language(s) while providing access to the effective acquisition of one or more additional languages. The right to choose the language of learning and teaching is vested in the individual. This right, however, is qualified by the fact that it has 'to be exercised within the overall framework of the obligation on the education system to promote multilingualism' (Ibid: 3 ). Interestingly, in this section of the document, no mention is made of any obligation on the part of the education system to facilitate learning of languages, even although one of the aims of the new policy is to 'pursue the language policy most supportive of general conceptual growth amongst learners...' (Ibid: 4).

The actual policy proposals are in two sections: Languages as a Subject and Language of Learning and Teaching. The latter section consists of one sentence which reads as follows: 'The language(s) of learning and teaching in a public school must be (an) official language(s)' (Ibid: 6).

A closer look at the Languages as Subjects section reveals some interesting contradictions, so it is necessary to include it in full.

All learners shall offer at least one approved language(s) ${ }^{2}$ as a subject in Grade 1 and 2. 
From Grade 3 (Std 1) onwards, all learners shall offer their language of learning and teaching and at least one additional approved language as subjects.

All language subjects shall receive equitable time and resource allocation.

The following promotion requirements apply to language subjects

In Grade 1 to Grade 4 (Std 2) promotion is based on performance in one language and Mathematics.

From grade 5 (Std 3) onwards, one language must be passed.

From Grade 10 to Grade 12 two languages must be passed, one on first language level, and the other on at least second language level. At least one of these languages must be an official language.

Subject to national norms and standards as determined by the Minister of Education, the level of achievement required for promotion shall be determined by the provincial education departments (Ibid: 5)

Broadly speaking, the aims of the policy are to facilitate learning and promote communication between South Africans through the development of 'additive bilingualism'. Since the term 'additive bilingualism' is open to different interpretations, it requires definition. On the one hand it is seen as realised in an educational situation

in which speakers of any language are introduced to a second language in addition to the continued educational use of the primary language as a language of learning. The second language is never intended to replace the primary language, rather it is seen as complementary to the primary language (Heugh et al., 1995: vi).

Other groups would view 'additive bilingualism' as realised in any situation in which the acquisition of a second language does not mean that the primary language is supplanted in its role of primary language. It could mean therefore that the two languages play different roles.

No matter which kind of 'additive bilingualism' one supports, in this context, the LiEP's requirements run counter to the development of 'additive bilingualism' with concomitant implications for the facilitation of learning and for the promotion of multilingualism. Except in Grades 10 to 12, only one language (as opposed to two prior to 1994) is compulsory for promotion purposes. This means that learners need not even have minimal competence in another language. In other words, learners could be less multilingual (in a formal sense) than in the past.

There are serious implications for learning. The underlying assumption in the policy statements is that language development will take place in content subject classes. It is not considered necessary for learners to develop their proficiency in the language which is being used as a medium of instruction by taking the language in question as a subject. But, as a colleague and I have argued elsewhere, ' given the very poor learning conditions existing at most schools and the virtual non-existence of a language across the curriculum approach, the chances of such language development happening are very slim indeed' (Desai \& Van der Merwe in press). In addition, given the general lack of awareness among teachers of the role of language in learning, the role of specialist language teachers developing learners' language abilities must be crucial.

Although the LiEPD is a serious attempt to address the linguistic inequities of the past, a number of implicit tensions run through the document. One of these is what I call the 'choice factor'. I am aware that the Soweto uprising of 1976 serves as a grim reminder that no state 
can afford the consequences of imposing an unwanted language on learners. However, the new policy errs on the side of allowing too much choice. During the apartheid era, promoting the use of African languages as languages of learning was often perceived as an attempt to 'ghettoise' African ${ }^{3}$ learners and deny them access to the mainstream of South African life. This perception persists. The situation we have at present means that without a public awareness campaign round language and learning issues, and a substantial injection of resources, both material and human, the prejudices of the past are likely to militate against a substantial number of individual learners' choosing African languages as languages of learning. In my opinion, unless the state plays a more interventionary role, the use of African languages as languages of learning is unlikely to extend beyond the initial years of schooling.

The 'choice factor' is further compounded by the pull of globalisation. The argument for an English-mainly policy is often based on the premise that since it is an international language, it offers access to opportunities. As Chinua Achebe has put it 'the fatalistic logic of the unassailable position of English' takes over (Achebe cited in Ngugi, 1986: 9).

If learners were acquiring English effectively, the problem would not be as great. However, proficiency in English remains an unattainable goal for most learners. This applies not only to English as a subject, but also to it as a language through which learners can access knowledge. The many academic development programmes offered to learners at tertiary level are, at least in part, evidence that there are many black students, even among the most successful of black learners, whose English is inadequate for academic purposes.

A closer look at the effect of language choice on the learners at an African township school will help elaborate this point.

\section{LANGUAGE IN EDUCATION POLICY IN PRACTICE}

School X, where I have conducted primary research on Grade 4 learners, is situated in Khayelitsha, a sprawling African township near Cape Town International Airport. The population is predominantly Xhosa-speaking. The 38 learners in the Grade 4 class all have Xhosa as their home language. So does their teacher. According to the Deputy Principal, the same applies to all the other classes. Despite the linguistic composition of the School X intake and the predominance of Xhosa in its immediate environment, the School decided in 1995 to introduce English as a medium at an early stage, i.e. Grade 4 instead of Grade5. The reason given to me by both the Deputy Principal and the teacher was that the parents were taking their children out of African township schools and sending them to the formerly Coloured schools because they wanted them to acquire English earlier. School X did not want to lose its quota of teachers through low pupil enrolments and therefore decided to introduce English as a medium earlier. This means that officially learners are supposed to do all their written work in English, with the exception of classes in Xhosa as a subject.

As part of my project, I sat in on this Grade 4 class during the Xhosa, English, Science and Mathematics periods on one day a week, during the months of April and May 1998, to get a sense of the linguistic practices of the teacher and the learners in this first year of the supposed shift to English as LoLT. Although officially the class was being taught through the medium of English, in practice the situation was rather different. Except during the English class, the teacher used mainly Xhosa to convey information to the learners, but referred them to the English in their textbooks from time to time and used English for technical terms such 
as names of birds (parrots, canary, owl). Textbooks, incidentally, were all kept at school, as there were not sufficient copies available for each of the learners to have one. Learners had to write in English for their final assessment.

Having gained a sense of the class ethos, I proceeded to the next phase of my research. I started with a fairly simple task, which was not content-subject based, as I thought it might reflect more accurately learners' current levels of proficiency in Xhosa and English. Learners were given a set of six pictures in an envelope (see Appendix 1). They had to arrange the pictures in such a way that they told a story. Learners were then asked to use the pictures as the basis for writing a story, first in Xhosa and then in English. The task instructions were translated into Xhosa for the class, orally and in writing, by a Xhosa-speaking colleague who accompanied me to the school for this purpose (see Appendix 2).

The results are revealing. I have chosen three scripts randomly to illustrate the point. My Xhosa-speaking colleague has done a literal translation of the Xhosa stories to highlight the contrast in proficiency in the two languages. Punctuation and capitalisation were largely absent from the Xhosa version, but these have been inserted into the literal translation for easier reading. The English stories are largely incomprehensible and often not even linked to the pictures, whilst the Xhosa versions are much more clearly expressed, but are in a descriptive rather than a narrative mode. This was true of all 38 scripts. On being asked in Xhosa how they experienced the task, all learners said that they had enjoyed the task but simply did not have the proficiency to express themselves in English clearly.

\section{Sample 1}

\section{Xhosa original}

Kwakuko utata waza wabeka ibhokisis yakhe phantsi encokola notata wakhe kwasukha kwathi gqi omnye ubhuti wathatha ibhoks yala tata wabaleka waleqwa ngumntwana omnye wakhalisa impempe omnye emkhemba wabaleka wayo kuqabela imoto wayiqhuba kakhula abanye bavula ibhokisis kwavela inyoka wathuswa yinyoka kwade swathaka idimasi.

\section{Translation into English}

There was a father (old man) who put his box down, conversing with his father. Then a brother appeared and took that old man's box and ran away. He was chased by a child and someone blew a whistle and another one pointed at him. He ran away with it and got into the car and drove very fast. The others opened the box and a snake appeared. One was so terrified by the snake so that his sunglasses fell off.

\section{English original}

Once upon a time

Long long ago

Ly Buter uteatsha fourboy late my father

I taket my tyesi

I goiu my father is gouiu boeke

Look my boy 


\section{Sample 2}

\section{Xhosa original}

Ubhuti wahamba nomtwana baya kwindawo zokuqabela ioropeni bafika kukho utata opephethe imantyi umntwana wathethisa lo tat wabe ubhuit ethatha le mantyi bableka nayo wabiza ipolisa alizange limve bahemba nayo bayivual kwee gqi inyoka enkula wothuka ubhuti zawa idimasi wothuka nomtwana.

\section{English translation}

A young man went with a child to the airport. When they arrived there was a father (old man) carrying a basket. The child talked to his father while the young man took the basket. They ran away with it. He called a policeman. The policeman didn't hear him. They went away with it. They opened it and a big snake appeared. The young man was startled/terrified. The sunglasses fell down. The child was startled.

Father going to kwaling my plyiner

Brother siking noFather tike manty

Going noy spiking Police open manty ckinkr

Big snaiking jamp hat leleng dimes

$$
\text { Stop The Story }
$$

\section{Sample 3}

Omnye utata umile ujongekude omnye utata uhamba nomntwana bama useke la mntwana wathetha nala tata usuke omnye wathatha imsntyi wsbeleka nayo nala mntwana wabaleka Wothuka la tat wajo emva Hayibo ayikho imantyi wayibona nobo bebaleka nayo wakhwaza heyi

Baqwa ngula tat nomnye yo ababaleka

Nabo bekwele imoto bebaleka ngayo

Bafika nyendawo bafika apho bavula la mantyi bayivual kwavela inyoka

\section{Translation into English}

On father is standing and looking away. Another father arrived with a child and they stood. Then this child spoke with that father. Then, the other took the basket and ran away with it. That child also ran. The father was shocked and looked behind. No! There is no basket. He saw it. There they ran. He shouted, 'Hey'.There, they are getting into the car, and escaping in it. They arrived at a certain place, when they arrived there they opened that basket. They opened it and a snake appeared.

\section{English original}

\section{This is a man is luck}

This boy is prat is the man. This is put the bag

Poliec check thi man aurineng the bag

I two poliec thu au poit the man and boy auraning the car

A man is raning in thi car 
A man and boy open aut the snack

Some Comments on the Samples

In the Xhosa versions,

- learners are able to depict what is happening in the pictures fairly accurately;

- sentences are complex;

- there is evidence of a fairly wide vocabulary, e.g. 'conversing', 'appeared' 'shocked';

- there is some evidence of an ability to use direct speech (see Sample 3);

- there are few spelling and grammatical errors;

- learners are not yet able to develop a story, but tend to describe what is happening frame by frame.

In the English versions,

- learners are not able to express themselves clearly;

- the writing sometimes has very little bearing on the pictures;

- there is little sense that a story is being told;

- there are a large number of spelling and grammar errors;

- sentences are generally very short;

- the ability to form sentences is at the emergent level only.

The pressures on this Khayelitsha school are common in South Africa. These results, then, suggest what is likely to be a much larger pattern, which must give cause for serious concern.

\section{THE DISJUNCTURE BETWEEN POLICY ON PAPER AND POLICY IN PRACTICE}

The primary aim of a new language in education policy is supposed to be facilitation of learning for all learners. At times it seems as if multilingualism of a particular kind is favoured at the expense of learning. I refer here to a view of multilingualism, which insists that one of the languages known should be English. The view that simply ignores the language strengths of the many black learners who are proficient in more than one African language is ironic. While I believe that learners should be given access to English, it should never be at the expense of formal learning.

Given the predominant role English plays in all aspects of South African public life (see, for example Ridge in print), it is not surprising that the majority of parents want their children to acquire English. It becomes problematic when they believe that the best way for their children to learn English would be to have it as a language of instruction. In some quarters, the promotion of home language for African language speakers is even seen as divisive and segregationist, because of the actions taken during apartheid.

South Africa is a diverse country with inequities in all domains of life. Language policy can be an important means of righting the balance for formerly disadvantaged learners. It is vital that the language policies at schools be decided on after very careful consideration of all factors. The linguistic strengths of learners and their teachers, and the linguistic environment (and the opportunities it provided for informal learning) are some of the important factors that 
have to be considered very carefully. The school that has been referred to in this article made a decision in terms of its own self-preservation. The decision to adopt a model that works in a very different context is clearly not in the interests of the learners concerned.

\section{REFLECTIONS ON THE FUTURE}

There are a number of ways in which we can ensure that learning is facilitated rather than frustrated. None of these is simple or short-term. First, black learners need to be given the opportunity to learn through their mother tongue. This will not occur unless quality classroom resources are developed and made available. Second, learners must be given real access to other languages. As I argued earlier, the role of language in learning is not generally understood. Unless black learners are given the opportunity to develop their proficiency in English to a point where it can be used as an effective learning tool, successful learning will not be possible. To gain real access they will have to be taught by skilled language subject teachers. I would argue that all learners, not just Africans, should learn an African language to promote more effective communication within and outside the school. An obvious implication is that the learning of an African language to at least a basic level of competence, should form part of the initial teacher education for those who do not already speak it. And in-service training courses should be provided for teachers who do not have at least a basic level of competence in an African language. This is essential if we are serious about fostering multilingualism. Even more importantly, really significant opportunities to facilitate learning and to honour the resources within the classroom will be lost.

It is clear that changes of this kind will have to be part of state policy. And the state will have to provide the financial resources to make these a reality. 

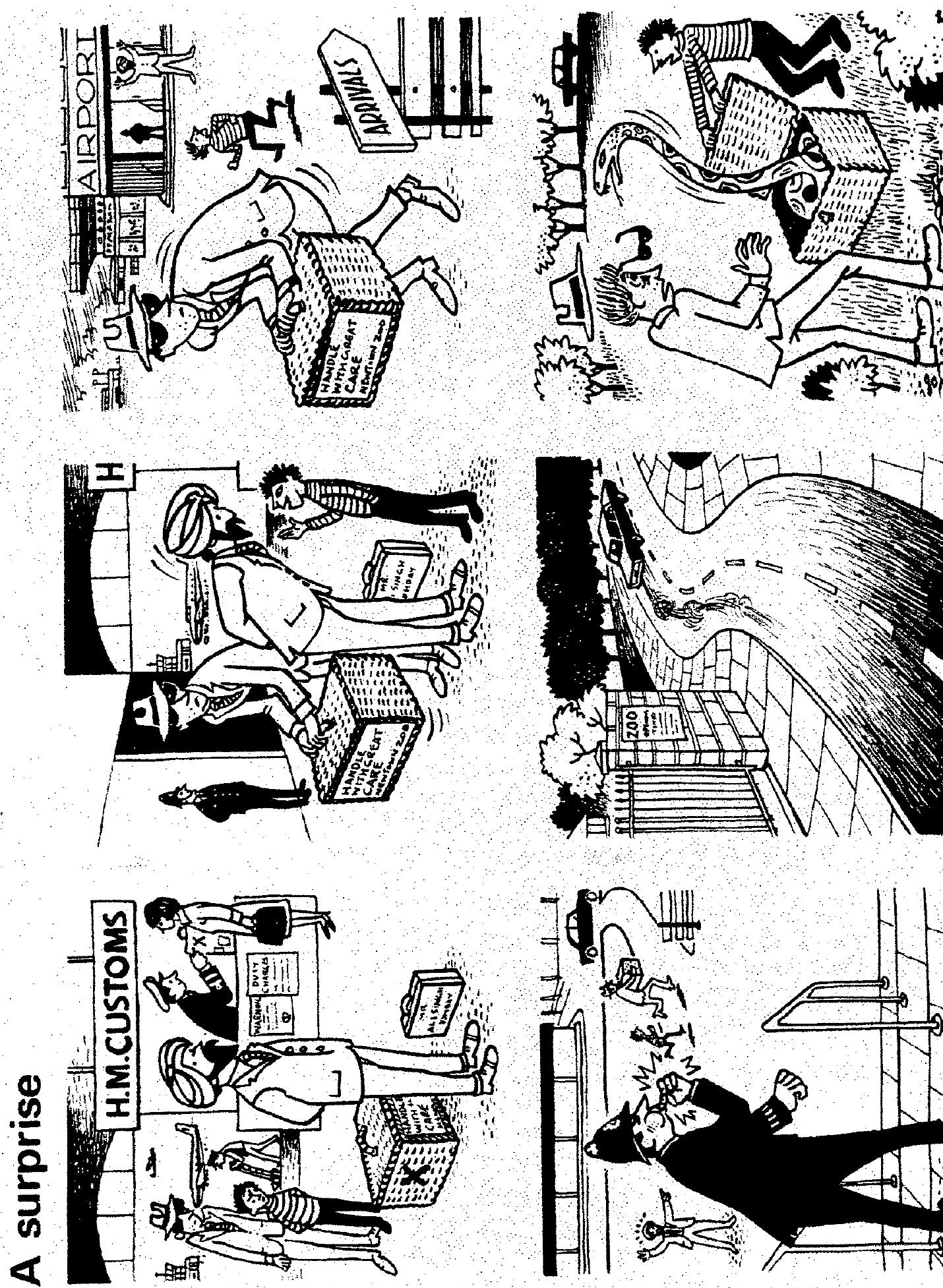
Appendix 2

Ibali Lemifanekiso

Iphepha Lemiyalelo

Phambi kokuba uqale ngalo msebenzi, bhal phantsi ezi nkcukacha zilandelayo kwiphepha lakho elinga nto:

Igama:

Ibanga:

Iminyaka/Ubudala

Ulwini oluthethayo:

Kukho imifanekiso emithandathu kwimvulophu yakho. Le mifanekiso ibhalisa ibali.

Khupha le mifanekso kwimvulophu.

Yimise ngendlela eyenza ukuba ibalise ibali.

Yinike amanani le mifanekiso ngendlela oyibeke ngayo ukusuka ku-1 ukuya ku-6

Ngoku, bhala ibali ngokubhekiselele kwimifanekiso ephepheni lakho.

Picture Story

Instruction Sheet

Before you start with the activity, write down the following information on your blank sheet of paper:

Name:

Standard:

Age:

Home Language:

There are six pictures in your envelope. These pictures tell a story.

Take the pictures from your envelope and look at them.

Arrange the pictures in such a way that they tell a story.

Number the pictures from 1 to 6 in order to write a story.

Now write a story as is shown in the pictures. 


\section{ENDNOTES}

1 Although Afrikaans is regarded as an African language, it is not included here. Since it has been actively developed as a language to be used in the public domain since 1925, it is not seen as requiring state resources for further development.

${ }^{2}$ The term 'approved languages' is defined in the LiEP document as follows:

The term 'approved languages' indicates that valid syllabuses at first or second language level have been submitted, and have been approved by the Minister as according with national policy. All official languages are approved languages, while German First language is also an 'approved' language for non-immigrant candidates. The Minister may submit a syllabus at first or second language level, for any language, for approval.

${ }^{3}$ African as used here does not include those formerly classified as Coloured or Indian.

\section{REFERENCES}

DESAI, Z \& N. TAYLOR. 1997. Language and Education in South Africa. In Coulby, D. Gundara, J \& Jones, C (eds) World Yearbook of Education 1997: Intercultural Education. London: Kogan Page.

DEPARTMENT OF EDUCATION (RSA) 1996a. Draft. Language Policy.

DEPARTMENT OF EDUCATION (RSA) 1996b. Norms and Standards regarding Language policy.

HEUGH, K, A SIEGRUHN \& P PLUDDEMANN. 1995. Multilingual Education for South Africa. Isando. Heinemann Publishers.

NGUGI WA THIONG'O. 1986. Decolonising the Mind. London: James Currey.

RIDGE, SGM. In print. Mixed motives: ideological elements in the support for English in South Africa. In Ricento, T (ed.) Ideology, politics and language policies: Focus on English. Philadelphia: John Benjamins.

REPUBLIC OF SOUTH AFRICA. 1996. Constitution of the Republic of South Africa (Act 108 of 1996). Pretoria: Government Printer. 